\title{
Public-Private Partnership as a Potentially Useful Formula in Polish Environmental Protection
}

Public-Private Partnership (further referred to as the PPP) is an economic as well as a legal formula. It occurs in different jurisdictions. In international law virtually no directly relevant regulations exist. Indirectly, the PPP occurs in areas of State's operational efficiency shortage (ocean bed exploration, satellite activities). In addition, sometimes postulated and/or promoted in works of UNDP, UNDESA, UNCSD, etc., the PPP is also present in non-binding documents of the European Union ${ }^{1}$. Until now - we are only dealing with strategic programming and promotion, however, from the Polish perspective the progress on the EU in the PPP area should be monitored. It is also worth participating in the process of shaping the EU PPP model, in case of future European legislation to avoid a possibly significant reconstruction of the national model. Currently, the Polish legislation on the PPP has a statutory form. After the failure of the Act of 28 July 2005 on public-private partnership - it was replaced by another

* Ph.D., Professor at University of Bialystok, University of Bialystok (Faculty of Law).

1 Further on the PPP: M. Bult-Spiering, G. Dewulf, Strategic Issues in Public-Private Partnerships. An international perspective, Blackwell Publishing, Oxford 2008. 


\section{Maciej Perkowski}

Act on PPP of 19 December 2008, which entered into force on 28 February 2009 , repealing the enforcement package associated with the previous law. The new law contains references to the European funds. It also introduces an appropriate link to environmental protection. The other issue today is facing enormous challenges, such as effective climate protection. It seems that the PPP may be used in the area. The opinions of consulted local authorities give an optimistic perspective, especially in regard to development of power industry and thermal economy (according to surveys). The progressive deficit in public finances, which unfortunately displays as a continuing trend, additionally makes the expansion of 'privatization' of public tasks safe for public interest and acceptable to the public more likely to occur. The newest practice indicates progression in the field. For these reasons, it is worth introducing the reader interested in environmental protection to basic information on public-private partnership.

\section{The Basis of PPP}

Public-Private Partnership (PPP) is a type of cooperation between public and private sectors to implement the investment or provision of services traditionally monopolized by the public sector ${ }^{2}$. The legal basis for publicprivate partnerships in Poland is the Act of 19 December 2008 on the public-private partnership ${ }^{3}$. It is supplemented considerably by the Act of 1 September 2009 on the concessions for works or services ${ }^{4}$, the Act of 29 January 2004 - Public Procurement $\mathrm{Law}^{5}$ and the Civil Code of 23 April $1964^{6}$.

The subject of the public-private partnership is a joint implementation of projects based on the division of tasks and risks between a public entity and a private partner. It is assumed that both parties derive a number of benefits

2 Cf. M. Perkowski, Wprowadzenie, w: Partnerstwo publiczno-prywatne. Zagadnienia teorii i praktyki, ed. idem (with the preface by C. Kosikowski), Temida2, Bialystok 2007, p. 8.

3 Dziennik Ustaw (hereinafter referred to as Journal of Laws) of 2009, No 19, item 100 and laws amended by it.

4 Journal of Laws of 2009, No 19, item 101.

5 Journal of Laws of 2007, No 223, item 1655 and Journal of Laws of 2008, No 171, item 1058.

\footnotetext{
Journal of Laws, No 16, item 93, with amendments.
} 
from it, according to their level of involvement in the implementation of specific tasks. By allowing each sector to do what they do best - services and public infrastructure are implemented in the most economically efficient way. The main objective of the PPP is, therefore, development of such relations between the parties under which the risk is borne by the party best capable of controlling it, while economic efficiency is achieved by the use of private sector resources.

The planned project may involve: construction or renovation work of a building, provision of services, execution of works, in particular equipping an asset with devices raising its value or utility or other services - combined with maintenance or management of a property component which is used to implement a public-private venture or is related to it. There are no clear restrictions related to particular businesses or trades, although the preferences of lawmakers can be deciphered from the changes made in other legislative acts. For example, when it comes to protecting the environment: 'The Act of 27 April 2001 - Environmental Protection Law in article 405 section 3 says: 3 . Resources from funds are also earmarked for co-financing of environmental protection and water management implemented on the terms specified in the Act of 19 December 2008 on the public-private partnership'.

In a contract of public-private partnership, the private partner undertakes to implement the project for remuneration and to bear in whole or in part costs of its implementation or to guarantee that a third party will incur them, and the public entity undertakes to cooperate for the achievement of the project objective, particularly providing own contribution. When its own contribution to the PPP project is in the form of an asset - it can (in particular) take the form of: sales, lending, usage, lease or tenancy. At the same time it is worth emphasizing that, "if an asset contributed by the public entity is used by the private partner in a way evidently contrary to its purpose specified in the contract of the public-private partnership, the private partner is obligated to transfer the asset to the public entity under the terms of the public-private partnership contract'. The Act explains that: 'if the financial contribution of the public entity consist of an in-kind contribution to a company, its transfer, in case of its misuse, is made on the terms specified in the contract or the statutes of the association'. On the other hand: 'if the asset was owned by the private partner, the private partner is entitled to reimbursement of the asset value as of the time of the transfer. Otherwise, the private partner can claim the necessary expenditures to the 


\section{Maciej Perkowski}

level not covered by benefits that it received from the asset. Reimbursement of other expenses may be claimed, should they increase the value of the asset at the time of transfer to the public entity. However, if the expenditures were made after the time when the public entity had requested the transfer in writing or learnt about the action for the transfer brought against it, it may demand reimbursement of the necessary expenses only'.

\section{Startup mode of PPP}

In its organizational and subjective aspect - the starting point of a PPP is a tender procedure. The public entity, after posting an offer in the Public Procurement Bulletin or publication of a notice in the Official Journal of the European Union, additionally publishes information on a planned public-private partnership in the Bulletin of Public Information (Biuletyn Informacji Publicznej). Private entities interested in joining the partnership shall submit their offers to the public partner. Then it chooses the best offer, which represents the best balance of payments and other criteria related to the project. The evaluation criteria, according to the law, are: the division of tasks and risks associated with the venture between the public entity and the private partner, the dates and amounts of envisaged payments or other funding by the public entity, if planned. Optionally, the criteria of the offer evaluation may also be: the division of the proceeds of the project between the public entity and the private partner, the ratio of the public entity's own contribution to the contribution of the private partner, the effectiveness of the project, including the efficient use of assets and criteria directly relating to the subject of the project, in particular quality, functionality, technical parameters, level of offered technologies, cost of maintenance, service. It should be noted that when the remuneration of the private partner consists of the entitlement to the benefits from the subject of the public-private partnership, or, above all, this right accompanied by a payment of a sum of money, the selection of a private partner is made by applying the provisions of the Act on concessions for works or services, with reference to the Act on the PPP. The private partner selection in other circumstances is done by applying the provisions of the Act of 29 January 2004 - Public Procurement Law, also taking into account the provisions of the Act on the PPP. 
Public-Private Partnership as a Potentially Useful Formula..

Under pain of nullity the legislator prohibits any changes to the provisions of the contract of the public-private partnership concerning the contents of the tender, under which the private partner was selected, unless the necessity of such changes is due to circumstances which could not be foreseen at the time of concluding the contract.

It should be noted that a private partner can put forward a proposal of a project, but the formal mode is launched by a public entity. For the clarity of solutions - private partners should secure propositions of projects, for example with copyrights, clearly informing about it, which seems to reduce the risk of inadvertent use of the concept proposed by a private partner in a PPP without its participation. It is worth remembering - given that the question - in the absence of adequate security - was the root of the failure of the previous Act on the PPP (of 2005).

Partners must be aware of the direct and indirect constraints that affect the financing of the PPP. Firstly, the legislator introduced the rule that the budget would be determined by the total amount up to which the government administration may incur financial obligations under contracts for public-private partnership in a given year. In this background a major constraint for large investments is provided in the disposition of Article 18:

'1. Financing of a project from the State budget in the amount exceeding PLN 100,000,000 shall require consent by the minister competent for public finance, excluding the funds allocated for financing of operational programs, that are specified in the Act of 6 December 2006 on principles of conducting the development policy (Journal of Laws, No 227, item 1658 and of 2007, No 140, item 984). In issuing the consent the minister competent for public finance shall consider the influence of the planned budget expenditures on safety of public finance.

2. The consent specified in section 1 shall be issued on application by the public entity containing:

1) definition of the public entity;

2) definition of the planned project;

3) projected amount of State budget funds allocated during individual budgeting periods for project implementation.

3. The ministercompetent for publicfinance shallissue or refuse the consent within six weeks as of the date of receipt of the application. The consent or refusal of a consent is not an administrative decision 


\section{Maciej Perkowski}

4. The public entity may file another application for issue of consent as specified in section 1 for implementation of the same project in case of a change in the data specified in section 2 point 3 . The provisions of section 3 shall apply to repeated filing of the application.'

Secondly - from 1 January 2011, the Order of the Minister of Finance of 23 December 2010 on the detailed method of classification of debts included in the public debt, including the Treasury debt (Journal of Laws, No 252, item 1692). In particular, section 3 point 2 of the regulation indicates that the category of credit and loans which are classified as debt titles of the public debt will be considered 'public-private partnership contracts affecting the level of the public debt'. On one hand, the point is that the formation of actual liabilities of the public partner to the private partner automatically charges the public finance sector debt. On the other hand, it is a situation in which the private partner will not take the risk of building and at least one of the risks - availability or demand upon itself. This provision is a consequence of implementing the guidelines of Eurostat (Eurostat Decision No 18/2004 of 11 February 2004, STAT/04/18) into the Polish law. Commentators point out that the Order of 23 December 2010 did not implement any changes to already existing regulations in this field and still, if the private partner assumes the risks associated with building and at least one of the following risks: demand and availability - commitments under public-private partnership contracts will not be included in the public finance sector debt ${ }^{7}$.

\section{The form of the PPP}

As for the organizational forms of an already running PPP - a local government unit can perform ad hoc partnerships or create a limited partnership or a joint-stock partnerships as referred in art. 14 section 1 of the Act. According to the latter regulation 'the contract of public-private partnership can provide that for the purpose of performance the public entity and the private partner shall establish a capital company, a limited partnership or a limited joint-stock partnership' and 'the public entity

7 For example: T. Korczyński, Niepotrzebny strach o PPP, Obserwatorfinansowy.pl, as of 22 February 2011. 
may not be the general partner in such a company'. It is important that the goal and business of the company may not exceed the scope specified in the contract of public-private partnership, subject to the rule according to which 'the body of government administration that established the company as the public entity shall exercise the rights of shares or stocks in the company belonging to the State Treasury'. In particular, it has the power to control implementation of the project by the private partner.

In practice, the following forms of investment are implemented:

Contracts for construction (subcontracting) and technical supervision are concluded between public and private entities to perform a specific range of design and construction, finishing works, delivery of equipment and tasks arising from the design and construction. The private sector entities do not engage their capital, they only perform works commissioned by the public sector. In the contract with the public sector on investment performance the risks of the private sector is limited to the risk of payment for the work.

Service contracts are concluded between the public and private entities for well-defined services on behalf of public authorities. Private companies do not engage their capital, performing infrastructure services to the community on behalf of public authorities. For their execution they are paid from the public sector. If services are payable, users of the services are charged by the public sector.

Contracts for management (OEM Contracts-operations and Maintenance contracts), private entities are responsible for operating and maintaining public infrastructure system or a specific device, under agreements with the public sector. Private managers are paid for work from the public sector, which usually reflects the results measured in physical gauges, such as the amount of water processed in sewage treatment plants or water quality standards specified in the regulations on environmental protection. Private entities often bear the cost of legal liability risks associated with exceeding quantitative and qualitative standards. As in the case of contracts for services, users of payable services pay for them to the public sector. Maintenance contracts are concluded at the level of local authorities for a period not exceeding 10 years (usually $3-5$ years) and include the provision of services for the local community. Their purpose is mainly to improve the operational and service activities in the field of economic infrastructure. Due to the limited ability to increase fees and reduce personnel costs, the contracts are less susceptible to political influence than other forms of private participation. Liability of private managers amounts to use of existing 


\section{Maciej Perkowski}

equipment and facilities, so as to ensure adequate performance and their proper condition, while the development of infrastructure and related expenditures remain vested in the public sector. Contracts for construction, technical supervision, services and maintenance contracts do not involve private sector capital. They take the form of a contract for a specific task or of a fee-for-task agreement.

The following forms of private involvement in cooperation with the public sector, however, are associated with temporary or indefinite time inclusion of private capital in public administration tasks.

Leases are concluded between public authorities and private entities. On their basis public entities provide infrastructure equipment to private operators to the time of use (for the duration of the contract) for a fee in regard to the portion of the used machinery value. Lease agreements are often concluded with contracts for management or concession contracts. Regarding contracts for management, due to their several year duration, leasing contracts relate to operating leases. In the case of the concession, lease usually takes the form of financial leasing. In relation to economic infrastructure lease contracts are common in countries undergoing system transformation. Prague may be an example, where the municipal authorities decided to transfer municipal water supply into lease for 30 years to a company in which the city has 100 percent shares. The lessee, in turn, has entered into a contract with an operating company who has obtained a longterm investment credit for the modernization of water supply network ${ }^{8}$.

Concessions are probably the most popular form of incorporating the private sector in financing the economic infrastructure. They are usually awarded through public tender, which should guarantee the possibility to choose an optimal solution in terms of price and effects on society from competing private sector entities. Concessions take various forms, and their essence is to issue permits by public authorities to invest and operate equipment or entire infrastructure systems, usually while preserving the right to regulate prices in a fixed range, usually for 20-30 years, by the public sector. During the concession time, the concessionaire runs the investment

8 T. Kuczborski, M Stańczuk, Jak zdobyć pieniadze, „Rzeczpospolita” 1999, No. 142, p. B3, as cited in: M. Wenclik, Sfera publiczna i prywatna - interakcje, in: Partnerstwo publiczno-prywatne. Zagadnienia teorii i praktyki, ed. M. Perkowski (with the preface by C. Kosikowskiego), Temida2, Bialystok 2007, p. 30. 


\section{Public-Private Partnership as a Potentially Useful Formula..}

process and operates equipment on their own behalf and at their own risk. The most important features of the concession agreement are:

1) transfer of responsibility for running the investment process to the private sector,

2) transfer of operation of infrastructure services to private entities, transfer of technical risk, operational risk and market risk to the private sector,

3) remuneration for private entities through fees paid directly by the users of these services.

For the time of the concession duration the ownership of assets is granted to the private sector. The public authorities shall agree with the licensee on the type and amount of future assets, and types of services. The private entity is a provider of services for consumers and enters in a direct relationship with them. This is the private entity that takes full responsibility for the level and quality of services provided. While investing other risks also occur, such as risks arising from the standards and indicators required from the private operator under the contract, as well as the risk of an adequate level of services for which the public sector previously was responsible. The contribution of private capital in concessions takes varied forms 9 . The following table shows the most frequent in practice forms.

\begin{tabular}{|c|c|c|}
\hline Used abbreviation & Original name & Polish translation \\
\hline BOT & Build-Operate-Transfer & $\begin{array}{l}\text { Zbuduj-eksploatuj- } \\
\text {-przekaż }\end{array}$ \\
\hline $\mathrm{BOO}$ & Build-Own-Operate & $\begin{array}{c}\text { Zbuduj-przejmij } \\
\text { na własność-eksploatuj }\end{array}$ \\
\hline $\mathrm{BT}$ & Build-Transfer & Zbuduj-przekaż \\
\hline BLT & Build-Lease-Transfer & $\begin{array}{c}\text { Zbuduj-weź } \\
\text { w leasing-przekaż }\end{array}$ \\
\hline $\mathrm{CAO}$ & Contract-Add-Operate & $\begin{array}{c}\text { Podpisz umowę- } \\
\text {-uzupełnij-eksploatuj }\end{array}$ \\
\hline DOT & Develop-Operate-Transfer & $\begin{array}{c}\text { Rozwiń } \\
\text {-eksploatuj-przekaż }\end{array}$ \\
\hline ROT & Rehabilitate-Operate-Transfer & $\begin{array}{c}\text { Odtwórz-eksploatuj- } \\
\text {-przekaż }\end{array}$ \\
\hline $\mathrm{ROO}$ & Rehabilitate-Own-Operate & $\begin{array}{c}\text { Odtwórz-przejmij } \\
\text { na własność-eksploatuj }\end{array}$ \\
\hline
\end{tabular}

9 Ibidem. 
Maciej Perkowski

\section{The problem of risk in the PPP}

While analysing responsibility of parties in the area of economic risks involved, it can easily be seen that it is one of the key issues in public-private partnerships. In order to significantly reduce the risk of a public party a public entity is entitled to an ongoing review of project implementation by a private partner, according to principles and procedures specified in the contract of public-private partnership. Although the law clearly favours concern about the public risk, the private risk is no less likely and severe, especially since the "wages of the private partner depend primarily on the actual use or actual availability of the public-private partnership object'. Nevertheless, the scope of responsibility is determined - in a 'mirror' way - by the package of contractual rights and obligations, where the private partner undertakes to implement the project for remuneration, and to bear in whole or in part implementation expenditures or to guarantee that they will be incurred by a third party, and the public entity undertakes to cooperate for the achievement of the project objective, in particular by their own contribution. The effects of inadequate performance and default of the obligation, especially penalties fixed by the contract or reduction in pay of the private partner or company, are specified in the PPP agreement.

The legislator provided another risk mitigation steps in case of transfer, succession, etc. At the outset it must be emphasized that disposal or encumbrance of: 1) the property, 2) the company within the meaning of article 55 of the Civil Code requires the consent of all partners or shareholders of a PPP company and the public entity shall have the right of first refusal of shares or shares of a private partner in the company, which can be performed within two months from the date of notification of the content of the agreement concluded with a third party by the private partner, unless the contract of public-private partnership provides for a longer term. Sale of stocks or shares by the private partner in violation of these rules is invalid. On the other hand, the right of first refusal under the conditions specified above, shall apply also to the private partner for a year after the end of the public-private partnership, unless: the final court ruling stated its responsibility for improper performance of obligations of the public-private partnership contract or the public entity has entered into another contract of public-private partnership with a new private partner (the term referred to does not run, and the one that has started is suspended for the duration 
of court proceedings in respect of liability for improper performance of obligations of public-private partnership contracts by the private partner or of the election of a new private partner).

Economic ventures - by assumption - aim at bringing in a profit. The PPP, although it performs selected public tasks, is of an economic nature. In this case proceedings involving the profit are determined in a PPP agreement and /or in statutes of PPP associations. At the end of the duration of the public-private partnership the private partner or company transfers an asset, which was used for the project, in non-deteriorated condition, concerning its use as a result of normal usage, to the public entity, unless the contract of public-private partnership provides otherwise. The agreement on publicprivate partnership may provide that the transfer of an asset will be in favour of state or local legal entity or commercial company with a local government unit or the State Treasury as a majority shareholder. The right of claim against the public entity or the private partner or company to transfer the asset expires after a period of ten years from the end of the duration of the public-private partnership.

\section{Practical aspects of PPP}

In contrast to the previous statutory regulation ${ }^{10}$, not only does the new law provide any barriers to apply for grants from the European funds, but on the contrary - it favours this action. In the Act of 6 December 2006 on the principles of development policy ${ }^{11}$ article 28 was amended by adding section 9 to it: '9. Within the Operational Programme projects referred to in section 1, implemented in the form of public-private partnership, under the Act of 19 December 2008 on public-private partnership, can also be co-financed'.

It seems that in Poland the idea of the PPP requires promotion directed not only to citizens (even though public perception is important, they will

10 Cf.: T. Dziurbejko, Koncepcja partnerstwa publiczno-prywatnego na tle doświadczeń we wdrażaniu interwencji funduszy strukturalnych Unii Europejskiej, [in:] Partnerstwo publicznoprywatne. Zagadnienia teorii i praktyki, ed.M. Perkowski (with the preface by C. Kosikowski), Temida2, Bialystok 2007, p. 114.

11 Journal of Laws, No 227, item 1658 and of 2007 No 140, item 984. 


\section{Maciej Perkowski}

not ultimately decide on the initiation of such cooperation), but precisely to the partnership entities: local governments and entrepreneurs. The first category of entities should theoretically be interested in such cooperation. The PPP is a way to cover budget deficit, because it is based on private sector investing. Local government would not have to be involved in the preparation of implementation stages (design development, construction of maps, selection of contractors, etc.). It is not also responsible for subsequent operation of generated objects. Everything depends on a type of investment and details of the agreement. However, the contract of publicprivate partnership is complex and long-term, and for this reasons it deters many local governments. Firstly, because of the fact that the decision to initiate a PPP must be preceded by a costly analysis. The analysis may show if the investment made in such a formula will benefit more than one with applying traditional methods. The expenditures are, therefore, subject to a considerable risk. Local governments (especially small ones) are not too sure whether they have intellectual resources sufficient to carry out the project. There is need for self-education of administration officials in this field ${ }^{12}$. A 'PPP Platform' - a tool offered to parties interested in the PPP by the Ministry of Regional Development seems to be a significant reinforcement factor. It aims to fill a gap concerning the government assistance in the preparation and implementation of PPP projects. The platform will provide a forum for exchanging information, experiences and best practices among local governments in implementation of specific projects. There are two immediate objectives of the Platform in the area of public-private partnerships:

- The first one is a successful implementation of projects currently being prepared and giving support to the public sector in order to prepare good projects for the next financial perspective 2014-2020.

- The second objective is to create conditions for free and creative action by public institutions and good preparation of their stuff. The direct experience and learning through taking actions will also help to improve legal and institutional solutions and best use of financial models.

12 See: K. Dziedzik, Co to znaczy partnerstwo publiczno-prywatne i jak się z nim przebic do spotecznej świadomości?, in: Partnerstwo publiczno-prywatne. Zagadnienia teorii i praktyki, ed. M. Perkowski (with the preface by C. Kosikowski), Temida2, Bialystok 2007, p. 11. 
The result of these actions should be, inter alia: dissemination of the PPP model, more efficient administration, lower costs of preparation of projects by providing ready-made standard documentation packages for use by contracting authorities. Any public entity shall be entitled to the support ${ }^{13}$.

The private sector, as it seems, should be interested in cooperation in the PPP framework. It is a chance to invest considerable sums in projects and services, for which demand is and will be continued at a predictable high level for a long time. Investors could also count on certain fiscal benefits, for example arising from the statutory elimination of double taxation. But there are also limitations. Firstly, the private sector in Poland is not yet as financially efficient as in the UK. The prospect of many years of waiting for reimbursement of costs and profits from investments may deter potential private partners. Just as the need to participate in competition procedures. Entrepreneurs take into consideration the fact that they will have to (as in procurement) compete with each other mainly by means of a price. Such a situation forces to resign from more modern, more efficient solutions, which would contribute in the future to bigger and faster profits from the project. Mental barriers can also be an obstacle in the implementation of the PPP in Poland. The private sector observes impediments in cooperation with the public sector in the form of the bloated bureaucracy of the latter. Unfortunately, many traders and analysts also fault the Act on PPP for bureaucracy ${ }^{14}$. The good news is that the new regulation takes into account some selected de lege ferenda demands made on the base of the previous act ${ }^{15}$.

The public sector should take an offensive approach. If not in the form of a statutory PPP, then at least on the basis of an ordinary civil law contract. It seems that if the legislator (instead of experimenting again with the Act) promoted the PPP as an unnamed contract and then, after its becoming commonly used, eventually introduced it into the Civil Code the paradigm of partnership would be much better perceived than it is, as it

13 See: www.ppp.gov.pl.

14 K. Dziedzik, Co to znaczy partnerstwo publiczno-prywatne... op. cit.

15 Cf.: M. Perkowski, Partnerstwo publiczno-prywatne w ujęciu strategicznym, in: Partnerstwo publiczno-prywatne. Zagadnienia teorii i praktyki, ed. M. Perkowski (with the preface by C. Kosikowski), Temida2, Bialystok 2007, p. 170 and the following.; J. Matwiejuk, Partnerstwo publiczno - prywatne szansq rozwoju wspólnot samorzqdowych w Polsce, in: Partnerstwo publiczno-prywatne. Zagadnienia teorii i praktyki, ed. M. Perkowski (with the preface by C. Kosikowski), Temida2, Bialystok 2007, p. 128. 


\section{Maciej Perkowski}

clearly points to big, strong entities and also such ventures. Meanwhile, the deficit requiring cross-sector support seems to outweigh on the completely opposite side. Believing in the 'wisdom of the market', there may be hope that as a result of government promotion and observation of pilot 'flagship' projects - the PPP in Poland will enter the stage of progression... But will it be applied in wider environment? ${ }^{36}$

According to surveys - the use of the PPP is seen in perspective of power industry development and thermal economy, not only because of the public finances deficit. In regard to natural resources a human applies the eternal paradigm 'to have a cake and eat it too'. Although the contradiction in the approach is a logical conclusion - in practice it is difficult to take logical decisions. Rules of democracy - the system in which interested in governing must take into account many needs of many interest groups, often marked by mutual or internal contradictions - are to be blamed for that. In the area of environmental protection - on one hand, it is ,not proper' to take negation, on the other, there is a fear to put oneself to the voters' criticism for considerable expenditure on 'intangible' actions. The impasse may be interrupted by introducing additional solutions which will be noncontradictory to the previously indicated ${ }^{17}$. It seems that the involvement of private funds in the financing of environmental protection, based on the PPP formula is likely to optimize environmental protection - at least in the Polish perspective.

The European Championship in football to be held in Poland in 2012 creates a particular opportunity to promote - both the PPP and climate protection. For example, based on the PPP form the construction of the A2 motorway section 'Nowy Tomyśl-Świecko' was completed - currently the largest investment project referring to the Euro 2012, and at the same time, taking into consideration environmental requirements. However, this is a unique project, one can say - a 'flagship' one. The PPP project 'Waste Management System for the City of Poznan', or its counterparts for Lodz and Plock are quite similar. It is important that some smaller-sized projects have been also carried out. So far their number is not significant (in total),

${ }_{16}$ An interesting image of the issue is presented in the Committee for European Integration analysis (Department of Integration Policy): Pakiet klimatyczno-energetyczny. Analityczna ocena propozycji Komisji Europejskiej, Warsaw 2008.

17 Po: S. L. Hoffman, The Law and Business of International Project Finance. Third Edition, Cambridge University Press, Cambridge 2009, p. 105 and n. 
but they seem to have a progressive direction (biogas, waste sorting, etc.). The initiation of the PPP is the hardest part. If the government benefits from it - it usually reaches to further PPP projects.

In detail - the concession mode dominates along with the PPP/PPL mode. A quite interesting and finding more and more recognition way to start saving investments on the PPP formula is the ESCO (energy saving company) cooperation model, also known as financing from savings, which is carried out on the basis on the Public Procurement Law. Most projects of this type were recorded in replacement and modernization/upgrade of street lighting systems and thermal modernization area. The concept of a tender based on the assumption that the private sector in return for remuneration, including expenses related to the ongoing operation of existing facilities modernized, will make necessary investments from their own resources to save energy, and due to them for an appointment time will be able to recover their involvement with an assumed profit. The selection criterion for a partner who undertakes to carry out modernization / expansion in the terms of the commission is the time in which the contractor - exploiting and maintaining infrastructure entrusted to them - will retrieve an amount assigned to this purpose from the budget of the public entity (i.e. the price criterion - an expenditure multiplied by the number of accounting periods). After the end of cooperation the public entity regains full control over their own infrastructure and are accounted on their own with an energy supplier at new, usually lower, prices. It is a potentially very beneficial solution for the local budget, but it requires choosing the right private partner, which, with reference to a strong position of local energy suppliers, not interested in significant decrease in its consumption, may not always bring the expected results, or even come to fruition (disputes about ownership lighting infrastructure).

It must be kept in mind that environmental protection consists also of upgrading industrial technology in the direction of energy saving and emission reductions. In this regard, the PPP can offer unusual perspectives. Commentators usually assume occurrence of positive feedback ${ }^{18}$. The responses shall be provided - as usual - in practice...

18 See: Innowacyjnośc dla ratowania klimatu, Gazeta.pl, as of 26 February 2010: http://gospodarka.gazeta.pl/firma/2029020,31560,6665017.html. 